\title{
Relationship of Ability of Family Caregivers and Society's Stigma to Prevent Relapse and Improve the Quality of Life for People with Mental Disorders
}

\author{
Agustin Widyowati $^{1,2 *} \mathbb{D}$, Bhisma Murti ${ }^{3}$, Aris Sudiyanto ${ }^{4}$ \\ ${ }^{1}$ School of Health Sciences Ganesha Husada, Kediri, East Java, Indonesia; ${ }^{2}$ Doctoral Program in Community Development \\ and Empowerment, Universitas Sebelas Maret, Surakarta, Indonesia; ${ }^{3}$ Masters Program of Public Health, Universitas Sebelas \\ Maret, Surakarta, Indonesia; ${ }^{4}$ Department of Psychiatric, Faculty of Medicine, Universitas Sebelas Maret, Surakarta, Indonesia
}

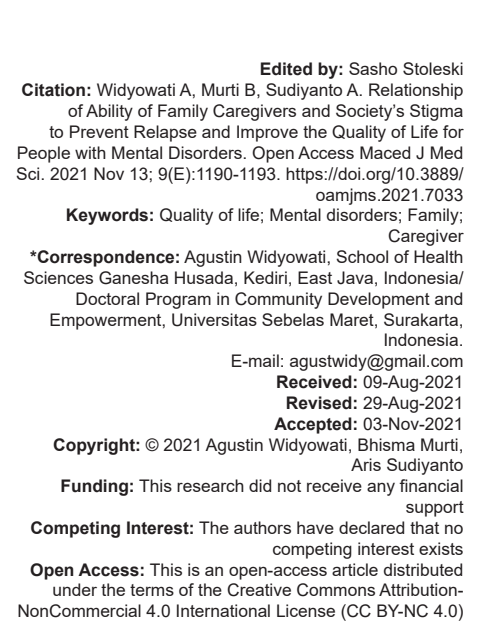

\section{Abstract}

BACKGROUND: People with mental disorders will experience a relapse even after 1 month of getting treatment or care from a health facility. The high recurrence rate can cause a decrease in quality of life. Efforts to prevent recurrence by involving family caregivers and reducing stigma from the community.

AIM: This study aims to analyze the relationship between the ability of family caregivers and community stigma to prevent recurrence and improve the quality of life of people with mental disorders.

METHODS: This study used a cross-sectional approach. The research location is in Kediri Regency, East Java, Indonesia. Sampling was done using the multistage random sampling technique. The number of samples is 76 respondents. The variables in this study were the ability of family caregivers, community stigma, disease recurrence, and quality of life for people with mental disorders. The data were analyzed using path analysis with the help of STATA 13.

CONCLUSION: There is a relationship between the ability of family caregivers and community stigma to preven recurrence and improve the quality of life of people with mental disorders.

\section{Introduction}

In Indonesia, the number of clients with severe mental disorders reaches $1.7 \%$ or $1-2$ people out of 1000 Indonesians have mental disorders [1]. This figure in 2018 increased by $5 \%$, namely, $7 \%$ or 7 out of 1000 Indonesians experiencing mental disorders [2]. The efforts made by the government in the field of mental health are contained in the policy of Law No. 18 of 2014 concerning mental health with various programs, namely, Indonesia is free from "pasung" 2017, the formation of Tim Pengarah Kesehatan Jiwa Masyarakat, and mental health integrated service post.

Globally, people with mental disorders will experience a relapse by $50-92 \%$ [3], can even experience a relapse after 1 month of getting treatment or care from a health facility [4]. In Indonesia, the recurrence rate of people with mental disorders is still high. Based on data from mental hospitals, the recurrence rate of mental disorders in Lampung is $71.3 \%$, Yogyakarta $75 \%$, and Semarang $68 \%$ [5], [6]. The high recurrence rate can cause a decrease in the quality of life of patients. The more often people with mental disorders experience relapses, it can cause progressive brain structure damage, cognitive deficits, impaired daily activities [7], [8], so it will experience a decrease in quality of life.

One of the efforts to prevent recurrence is to involve family caregivers and reduce stigma from the community. The frequency of schizophrenic recurrence has decreased after the involvement of the caregiver in providing care in every patient's activity [9], [10]. Community stigma will prevent patients from seeking treatment, thereby increasing the risk of recurrence [11]. This study aims to analyze the relationship between the ability of family caregivers and community stigma to prevent recurrence and improve the quality of life of people with mental disorders. 


\section{Methods}

This study used a cross-sectional approach. The study was conducted at a public health center in Kediri Regency. Sampling was done using the random sampling technique. The number of samples is 76 respondents with inclusion criteria Families and people with mental disorders who are cooperative and literate, people with mental disorders who are cared for by their families/caregivers, people with mental disorders with schizophrenia. The variables in this study were the ability of family caregivers, community stigma, disease recurrence, and quality of life for people with mental disorders. Data were analyzed using path analysis with the help of STATA 13. Research ethics approval was obtained from the health research ethics committee of RSUD Dr. Moewardi Faculty of Medicine, Universitas Sebelas Maret Surakarta Number: 439/III/HREC/2019.

\section{Results}

Table 1 shows that most caregivers (67.1\%) are aged 46-65 years, most respondents (51.3\%) are male, most respondents $(51.3 \%)$ have basic education, and a few respondents $(28.9 \%)$ have jobs. Self-employed, a small proportion of respondents $(21.1 \%)$ are cared for by their wives, most of the caregivers $(65 \%)$ care for patients with more than 5 years.

Table 1: Characteristics of respondents

\begin{tabular}{|c|c|c|}
\hline Characteristics & Frequency (respondent) & Percentage \\
\hline \multicolumn{3}{|l|}{ Age } \\
\hline $12-25$ years & 1 & 1.3 \\
\hline $26-45$ years & 24 & 31.6 \\
\hline $46-65$ years & 51 & 67.1 \\
\hline \multicolumn{3}{|l|}{ Gender } \\
\hline Male & 39 & 51.3 \\
\hline Female & 37 & 48.7 \\
\hline \multicolumn{3}{|l|}{ Education level } \\
\hline Basic education & 39 & 51.3 \\
\hline Middle education & 35 & 46.1 \\
\hline Higher education & 2 & 2.6 \\
\hline \multicolumn{3}{|l|}{ Employment } \\
\hline Entrepreneur & 22 & 28.9 \\
\hline Farmer & 17 & 22.4 \\
\hline Employees & 2 & 2.6 \\
\hline Housewife & 10 & 13.2 \\
\hline Merchants & 9 & 11.8 \\
\hline Farm workers & 2 & 2.6 \\
\hline Retired & 2 & 2.6 \\
\hline Private & 11 & 14.5 \\
\hline $\begin{array}{l}\text { Government } \\
\text { employees }\end{array}$ & 2 & 1.3 \\
\hline \multicolumn{3}{|l|}{ Caregiver relationship } \\
\hline Wife & 16 & 21.1 \\
\hline Father & 15 & 19.7 \\
\hline Sister & 13 & 17.1 \\
\hline Son & 8 & 10.5 \\
\hline Mother & 9 & 11.8 \\
\hline Husband & 8 & 10.5 \\
\hline Brother & 5 & 6.6 \\
\hline Niece & 1 & 1.3 \\
\hline Aunt & 1 & 1.3 \\
\hline \multicolumn{3}{|l|}{ Long time caring } \\
\hline$<2$ years & 1 & 1.3 \\
\hline $2-5$ years & 10 & 13.2 \\
\hline$>5$ years & 65 & 85.5 \\
\hline
\end{tabular}

Figure 1 shows that the path analysis with the help of STATA 13 shows the effect of the ability of family caregivers and community stigma on recurrence simultaneously, the effect of recurrence on the quality of life of patients. The results of the coefficient values for each variable in each path are shown in Table 2.

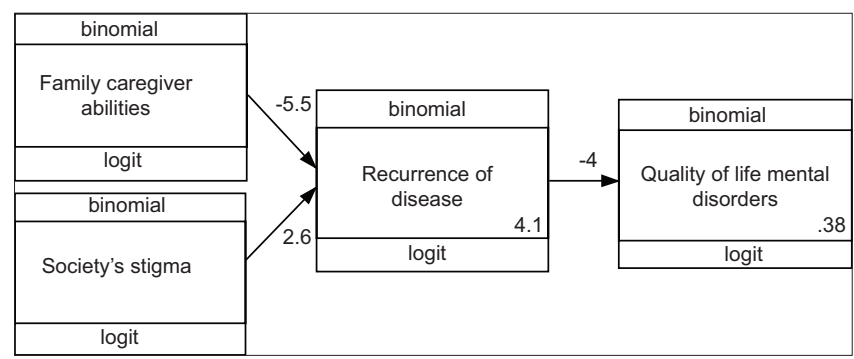

Figure 1: Model fit and parameter estimation

Table 2 shows that the quality of life of patients has a direct and negative relationship with disease recurrence. Patients with frequent disease relapses had a 4.02 unit lower probability (log odds) of reducing their quality of life $(b=-4.02 ; 95 \%$ confidence interval $[\mathrm{Cl}]=-6.11--1.93 ; \mathrm{p}<0.001)$ than patients with rare disease recurrence.

Disease recurrence has a direct relationship with community stigma and the ability of family caregivers. Stigma from the community, had a probability (log odds) of increasing disease recurrence by 2.61 units higher $(b=2.61 ; 95 \% \mathrm{Cl}=0.27-4.95 ; p=0.029)$ than patients who did not receive community stigma. The high ability of family caregivers has the possibility (log odds) to reduce disease recurrence by 5.54 units lower $(b=-5.54,95 \% \mathrm{Cl}=-7.89--3.20, p<0.001)$ than patients who have low family caregivers ability.

\section{Discussion}

The results of the path analysis show that the quality of life of people with mental disorders is indirectly influenced by the ability of family caregivers through disease recurrence. The higher the ability of family caregivers to contribute to caring for people with mental disorders so that they can reduce relapses and improve the quality of life of people with mental disorders. The ability of family caregivers is the knowledge and skills possessed by family caregivers with support from health workers/cadres, families, and communities. The abilities of family caregivers include early detection of relapse, emotional expression, self-efficacy, caregiver coping, and monitoring of medication adherence. The frequency of relapse of schizophrenia has decreased after the involvement of family caregivers in every patient activity [9]. Schizophrenic patients if they get maximum care from their families, relapse will be reduced [12]. Families as caregivers can experience feelings of chronic boredom and are in a state of extreme exhaustion, 
Table 2: Results of path analysis

\begin{tabular}{|c|c|c|c|c|c|}
\hline \multirow[t]{2}{*}{ Dependent Variable } & \multirow[t]{2}{*}{ Independent Variable } & \multirow{2}{*}{$\begin{array}{l}\text { Path coefficient } \\
\text { (b) }\end{array}$} & \multicolumn{2}{|l|}{$95 \% \mathrm{Cl}$} & \multirow[t]{2}{*}{$\mathrm{p}$} \\
\hline & & & Lower limit & Upper limit & \\
\hline Quality of life (Low) & & & & & \\
\hline$\overleftarrow{\text { Recurrence of disease (Often) }}$ & Recurrence of disease (Often) & -4.02 & -6.11 & -1.93 & $<0.001$ \\
\hline$\leftarrow$ & Community stigma (High) & 2.61 & 0.27 & 4.95 & 0.029 \\
\hline$\leftarrow$ & Ability of family caregivers (Low) & -5.54 & -7.89 & -3.20 & $<0.001$ \\
\hline $\mathrm{N}$ observation ketera $=76$ & & Note: & & & \\
\hline
\end{tabular}

decreased interest in life, low self-esteem, and gradually disappearing empathy for sufferers can result in a lack of support in caring for patients so that the patient's recovery is not optimal [13]. Burnout can be overcome by providing support both formally (health workers) and informally (family and social support). Health workers need to build a therapeutic relationship with the ability of family caregivers to motivate the ability of family caregivers to carry out their role in caring for people with mental disorders [14] by involving mental health cadres (Caplan, 2013). In facing difficulties, caregivers need support from the surrounding environment, both from family, friends, neighbors, and the surrounding community [15].

The positive stigma that exists in society is in a low category. Possibly caused by the feeling of fear felt by the community if the sufferer rages or injures others [16]. This stigma makes it difficult for sufferers to interact socially [17], thereby preventing the patient from seeking professional help and increasing the risk of recurrence [10]. Disease recurrence in this study included frequent. The high rate of recurrence experienced by patients can affect their quality of life. The impact of recurrence of clients with mental disorders can result in drug resistance, progressive brain structure damage, personal distress, difficulties in the client's rehabilitation process, anxiety, non-adherence to treatment due to lack of knowledge, and side effects of treatment [7], and cognitive deficits (e.g., memory, attention, and executive function) are associated with greater functional disability and impairment in daily activities (housework, grocery shopping, managing finances) [8], thus affecting the quality of life of people with mental disorders.

\section{Conclusion}

There is a relationship between the ability of family caregivers and community stigma to prevent recurrence and improve the quality of life of people with mental disorders.

\section{References}

1. Kementerian Kesehatan RI. Laporan Nasional Riskesdas 2013. Lembaga Penerbit Badan Penelitian dan Pengembangan
Kesehatan; 2013. https://doi.org/10.14203/press.298

2. Riskesdas. Laporan Nasional Riskesdas 2018. Badan Penelitian dan Pengembangan Kesehatan; 2018.

3. Weret ZS, Mukherjee R. Prevalence of relapse and associated factors in patient with schizophrenia at Amanuel mental specialized hospital, Addis Ababa, Ethiopia: Institution based cross sectional study. J Interdiscip Multidiscip Res. 2014;2(1):184-92. https://doi.org/10.1186/s12888-014-0259-y

4. Maehira Y, Chowdhury El, Reza M, Drahozal R, Gayen TK, Masud I, et al. Factors associated with relapse into drug use among male and female attendees of a three-month drug detoxification-rehabilitation programme in Dhaka, Bangladesh: A prospective cohort study. Harm Reduct J. 2013;10(1):14 https://doi.org/10.1186/1477-7517-10-14 PMid:24004685

5. Pribadi T, Yansuri Y, Maulana I. Relationship between family knowledge and recurrence of schizophrenia patients in a mental hospital in Lampung Province. Malahayati Nurs J. 2019;1:23947. https://doi.org/10.33024/manuju.v1i2.1457

6. Dewi R, Marchira C. Family history of mental disorders with recurrence of schizophrenia patients at the DR. Sardjito Yogyakarta. Ber Kedokt Masy. 2009;25(4):176-9.

7. Kazadi NJ, Moosa MY, Jeenah FY. Factors associated with relapse in schizophrenia. S Afr J Psychiatry. 2008;14(2):52-62. https://doi.org/10.4102/sajpsychiatry.v14i2.158

8. Kim JM, Chalem Y, di Nicola S, Hong JP, Won SH, Milea D. A cross-sectional study of functional disabilities and perceived cognitive dysfunction in patients with major depressive disorder in South Korea: The PERFORM-K study. Psychiatry Res. 2016;239:353-61. https://doi.org/10.1016/j. psychres.2016.01.022 PMid:26908289

9. Epstein-LubowG, GaudianoBA, HinckleyM, Salloway S, MillerIW. Evidence for the validity of the American medical association's caregiver self-assessment questionnaire as a screening measure for depression. J Am Geriatr Soc. 2010;58(2):387-8. https://doi.org/10.1111/j.1532-5415.2009.02701.x PMid:20370867

10. Eni KY, Herdiyanto YK. Family social support for the recovery of people with schizophrenia in Bali. J Psikol Udayana. 2018;5(2):268-81. https://doi.org/10.24843/jpu.2018.v05.i02. p04

11. Florescu S. $12^{\text {th }}$ European Public Health Conference 2019-01: Poster Walks 311. Vol. 22; 2019. p. 2019.

12. Buckley PF, Foster A. Schizophrenia: Current concepts and approaches to patient care. Am Health Drug Benefits. 2008;1(4):13-22. PMid:25126229

13. Ebrahimi $H$, Seyedfatemi $N$, Areshtanab $H N$, Ranjbar $F$ Thornicroft G, Whitehead B, et al. Barriers to family caregivers' coping with patients with severe mental illness in Iran. Qual Health Res. 2018;28(6):987-1001. https://doi. org/10.1177/1049732318758644 PMid:29478404

14. Cheng JF, Huang $\mathrm{XY}$, Hsu YS, Su CH. Influencing factors of community mental health nurses caring 
for people with schizophrenia in Taiwan. J Psychiatr Ment Health Nurs. 2012;19(4):319-26. https://doi. org/10.1111/j.1365-2850.2011.01795.x

PMid:22070523

15. Oktaviana A. Hubungan locus of control dan dukungan sosia dengan resiliensi pada remaja penyandang tuna rungu. Psikoborneo. 2013;1(1):1-5.

16. Mestdagh A, Hansen B. Stigma in patients with schizophrenia receiving community mental health care: A review of qualitative studies. Soc Psychiatry Psychiatr Epidemiol. 2014;49(1):79-87. https://doi.org/10.1007/s00127-013-0729-4

\section{PMid:23835576}

17. Girma E, Tesfaye M, Froeschl G, Möller-Leimkühler AM, Müller N, Dehning S. Public stigma against people with mental illness in the Gilgel Gibe Field Research Center (GGFRC) in Southwest Ethiopia. PLoS One. 2013;8(12):e82116. https://doi. org/10.1371/journal.pone.0082116

PMid:24324756 